\section{New cassava cultivars for starch and flour production in the Cerrado of Central Brazil}

\section{Eduardo Alano Vieira ${ }^{{ }^{*}}$, Josefino de Freitas Fialho ${ }^{1}$, Charles Martins de Oliveira ${ }^{1}$, Maria Madalena Rinaldi ${ }^{1}$ and Francisco Duarte Fernandes ${ }^{1}$}

\begin{abstract}
The cassava cultivars BRS 417, BRS 418 and BRS 419 are the first specifically developed for flour and starch production in the Cerrado biome of Central Brazil. They are promising for higher yields, lower production costs (mechanical planting) and the increase of genetic variability in cassava crops.
\end{abstract}

Keywords: Manihot esculenta Crantz, plant breeding, mechanical agriculture.

\section{INTRODUCTION}

Cassava root in Brazil is mainly grown for industrial purposes such as flour and starch production. Cassava flour is mostly produced by small industrial family units across the Brazilian territory, although there are some larger companies in the business, mainly in the states of Paraná, Santa Catarina and Mato Grosso do Sul (Valle and Lorenzi 2014). Starch, on the other hand, is usually produced at larger scales, although there are small units spread throughout Brazil, concentrated in the states of Paraná, Mato Grosso do Sul, São Paulo and Santa Catarina.

In the states where large cassava processing industries predominate, cassava cultivation has come under increasing competitive pressure for cultivation areas with other crops such as soybean, maize and sugarcane (Vilpoux 2008). This indicates the need for a diversification of the cassava cultivation areas for industrial use (flour or starch production) in Brazil.

The ecoregion of the Cerrado, which covers about $23 \%$ of the Brazilian territory (Klink and Machado 2005), is regarded as one of the world's last agricultural frontiers (Sano et al. 2019). The climate and soil in this region are favorable for cassava cultivation, i.e., the Cerrado is an alternative cultivation area for the diversification of cassava production areas in Brazil.

In spite of the production potential of the Brazilian Cerrado region for cassava, currently only $13.4 \%$ of the crop area and $11.8 \%$ of the national cassava output are located in the region, where a mean yield of only $13.02 \mathrm{t} \mathrm{ha}^{-1}$ is produced on an area of 210,826 ha (IBGE 2016). Two factors are the major causes for this low cassava production in the region: insufficient application of modern agricultural technologies by producers (lack of knowledge and/or financial difficulties); and lack of cultivars developed and selected specifically for flour and starch production in this biome.
Crop Breeding and Applied Biotechnology 20(2): e27362023, 2020 Brazilian Society of Plant Breeding. Printed in Brazil http://dx.doi.org/10.1590/198470332020v20n2a19

(1) 


\section{EA Vieira et al.}

To solve the above problems, the cassava breeding program of Embrapa Cerrado addressed the development of specific cultivars for flour and/or starch production in the Cerrado region of Central Brazil. Ideal cultivars should produce high starch yields, have white pulp, be resistant to pests and diseases and have a favorable architecture for crop management and mechanical planting (adaptation to large-scale cultivation) (Carvalho et al. 2011, Vieira et al. 2011, Vieira et al. 2018, 2019).

To meet the demand for cassava flour and starch production, specific cultivars for the cultivation conditions of the Cerrado of Central Brazil are being released by Embrapa Cerrados, namely the cultivars BRS 417, BRS 418 and BRS 419.

\section{BREEDING METHOD}

The cassava cultivars BRS 417, BRS 418 and BRS 419 for flour and/or starch production were selected from segregating populations, derived from crosses among varieties deposited in the Banco Regional de Germoplasma do Cerrado (BGMC), namely: BGMC 1304 (clone 9661/06) x BGMC 788 (IAC 14), BGMC 1304 (clone 9661/06) x BGMC 56 (Branca de Santa Catarina) and BGMC 982 (IAPAR 19) x BGMC 436 (IAC 12-829), respectively. The crosses were made in the 2007/2008 growing season. The resulting seeds were taken to the laboratory and soaked in water to test their viability; floating seeds were immediately discarded and the submerged ones dried at room temperature. The seeds were left to germinate in a greenhouse and the seedlings transferred to the field 45 days after emergence.

In all breeding stages, the crops were planted in November of the respective year and the recommendations for cassava cultivation in the Brazilian Cerrado were implemented in all treatments (Fialho et al. 2013, Fialho and Vieira 2013). In two selection cycles (2008/2009 and 2009/2010), evaluations were carried out 12 months after planting, while in the other selection cycles, the agronomic evaluations were performed 18 months after planting.

As the cassava plants grown from seeds have a pivotal root system, the main selection criteria applied in the first selection cycle (growing season 2008/2009) were: i) white tuberous root pulp; ii) architecture (high plant height and high height of the first branch); and iii) bacterial resistance. The selected seedlings were cloned and planted in the field from stem cuttings, in rows of five plants, at a spacing of 0.60 between plants and 1.00 between rows, prior to the second selection cycle.

In the second selection cycle (2009/2010), when cassava plants began to be propagated vegetatively by stem cuttings, and when they had developed a tuberous root system typical of commercial plantations, the following selection criteria were addressed: i ) architecture (high plant height and high first branch height); ii) bacterial resistance; iii) root yield; and iv) starch content in tuberous roots. The clones selected in this selection cycle were planted in blocks of five rows spaced $1.00 \mathrm{~m}$ with five plants spaced 0.60 apart, followed by the third selection cycle.

The third selection cycle (2010/2012) was also carried out at Embrapa Cerrados. The same criteria as during the second cycle were used for selection. The clones selected in the third selection cycle were subjected to the distinguishability, homogeneity and stability tests of cassava (Manihot esculenta Crantz) cultivars of the Ministry of Agriculture, Livestock and Food Supply (MAPA), in the 2011/2013 and 2012/2014 growing seasons. At this stage, in addition to the parameters evaluated in the previous two selection cycles, the root hydrocyanic acid content $\left(\mathrm{HCN}-\right.$ in $\left.\mathrm{mg} \mathrm{kg}^{-1}\right)$ of five randomly selected storage roots per plot was also estimated, based on the qualitative method described by Willams and Edwards (1980).

\section{PERFORMANCE CHARACTERISTICS}

The cultivars for cassava flour and/or starch production BRS 417, BRS 418 and BRS 419 were evaluated in experiments in three growing seasons: in 2012/2014 i) Bela Vista de Goiás (GO); ii) Planaltina (DF); iii) Rio Pardo de Minas (MG); and iv) Unaí (MG); in 2013/2015: i) Bela Vista de Goiás (GO); ii) Lagoa Formosa (MG); iii) Rio Pardo de Minas (MG); and iv) Unaí (MG); and in 2014/2016: i) Lagoa Formosa (MG); and ii) Rio Pardo de Minas (MG).

The crops were planted in November and harvested 18 months later. The agricultural practices were applied according to the recommendations for cassava cultivation in the Brazilian Cerrado (Fialho et al. 2013, Fialho and Vieira 2013). The experiment was arranged in a randomized complete block design with three replications. Each plot consisted of four 10-plant rows, spaced at $0.60 \mathrm{~m}$ between plants and $1.00 \mathrm{~m}$ between rows, and 16 plants per plot were evaluated. 
Cultivar IAC 12-829 was used as control, identified as 'BGMC 436' in the Cerrado Cassava Germplasm Bank (BGMC), which is the most widely planted cultivar in the Cerrado region of Central Brazil.

The following traits were assessed in the harvested cassava plants: i) height of the first branch (FBH - in $\mathrm{m}$ ); ii) plant height ( $\mathrm{PH}-$ in $\mathrm{m})$; iii) root weight ( $\mathrm{RW} \mathrm{-} \mathrm{in} \mathrm{kg} \mathrm{ha}^{-1}$ ); iv) starch percentage in roots (RSt) by the hydrostatic balance method; and v) starch yield (StY - in $\mathrm{kg} \mathrm{ha}^{-1}$ ).

The new cassava cultivars BRS 417, BRS 418 and BRS 419 for flour and/or starch production and the control have a high starch yield per hectare and moderate bacterial resistance and an advantageously high first branch height (FBH) and high plant height (PH) (Tables 1 and 2). Both FBH and PH are important traits, for being correlated with ease of cultivation, availability of stem cuttings and suitability for mechanical planting; genotypes with a higher FBH and total $\mathrm{PH}$ are therefore preferred (Vieira et al. 2018).

Suitability for mechanical planting is essential for cassava cultivation in the Cerrado region of Central Brazil, where predominantly medium and large crops are grown. This is an issue, since the currently recommended cultivar, the most planted in the region (cv. IAC 12-829), is unfit for mechanical planting (Vieira et al. 2015).

Cultivar BRS 417, with a mean root yield of $38.005 \mathrm{~kg} \mathrm{ha}^{-1}$, root starch percentage of $31.53 \%$, starch yield of 11,984 $\mathrm{kg} \mathrm{ha}^{-1}$ and favorable architecture for mechanical planting, has the advantage of medium-length roots (which greatly facilitates mechanical harvesting). On the other hand, cv. BRS 418 has a mean root yield of $38,940 \mathrm{~kg} \mathrm{ha}^{-1}$, a root starch percentage of $32.35 \%$, starch yield of $12,651 \mathrm{~kg} \mathrm{ha}^{-1}$, a favorable architecture for mechanical planting, and a light brown external root color (which facilitates peeling in the processing industry). Lastly, cv BRS 419 has a mean root yield of $42,010 \mathrm{~kg} \mathrm{ha}^{-1}$, root starch percentage of $30.29 \%$, starch yield of $12,870 \mathrm{~kg} \mathrm{ha}^{-1}$, a favorable architecture for mechanical planting and produces the highest absolute mean starch yield.

In summary, the cultivars BRS 417, BRS 418 and BRS 419 are promising new options of cultivation for cassava producers in the Cerrado region, with a view to increasing yields and reducing production costs (mechanical planting), aside from increasing the genetic diversity of crops.

\section{REGISTRATION, PROTECTION, BASIC PLANT STOCK AND LICENSED SEED MANUFACTURERS}

The cultivars BRS 417, BRS 418 and BRS 419 for starch and flour production were registered by the National Cultivar Registry (RNC) and the National Plant Variety Protection Service (SNPC) of the Ministry of Agriculture, Livestock and

Table 1. Trait means: first branch height (FBH - in $\mathrm{m})$, plant height ( $\mathrm{PH}$ - in $\mathrm{m})$, root weight (RW - in $\mathrm{kg} \mathrm{ha}^{-1}$ ), root starch percentage (RSt) and starch yield (StY - in kg ha-1), evaluated in 10 experiments in the growing seasons of 2012/2014, 2013/2015 and 2014/2016, in Bela Vista de Goiás (GO), Planaltina (DF), Rio Pardo de Minas (MG), Unaí (MG) and Lagoa Formosa (MG)

\begin{tabular}{lccccc}
\hline Clones & FBH & PH & RW & RSt & StY \\
\hline BRS 417 & $1.07 \mathrm{~A}^{*}$ & $2.75 \mathrm{~A}$ & $38005 \mathrm{~B}$ & $31.53 \mathrm{~A}$ & $32.35 \mathrm{~A}$ \\
BRS 418 & $1.14 \mathrm{~A}$ & $2.79 \mathrm{~A}$ & $38940 \mathrm{~B}$ & $1984 \mathrm{~A}$ \\
BRS 419 & $0.80 \mathrm{~B}$ & $2.35 \mathrm{~B}$ & $42010 \mathrm{~A}$ & $30.29 \mathrm{~A}$ & $12651 \mathrm{~A}$ \\
IAC 12-829 (control) & $0.53 \mathrm{C}$ & $2.02 \mathrm{C}$ & $37726 \mathrm{~B}$ & $31.32 \mathrm{~A}$ & $11861 \mathrm{~A}$ \\
\hline
\end{tabular}

"Means in a column followed by equal letters belong to the same cluster by the Scott and Knott test (5\% probability).

Table 2. Main morphological traits and root contents of hydrocyanic acid in ppm (HCN) of cassava cultivars BRS 417 , BRS 418 and BRS 419 for starch and flour production

\begin{tabular}{|c|c|c|c|}
\hline Characteristic & BRS 417 & BRS 418 & BRS 419 \\
\hline External root color & Dark-brown & Light-brown & Dark-brown \\
\hline Root pulp color & white & white & white \\
\hline Petiole color & reddish-green & reddish-green & purple \\
\hline Surface stem color & light-brown & silver & dark-brown \\
\hline Root length & medium & long & long \\
\hline Bacterial blight resistance & moderate & moderate & moderate \\
\hline
\end{tabular}


Food Supply (MAPA), under the numbers RNC 37616 and SNPC 20180197, RNC 37615 and SNPC 20180196 and RNC 37614 and SNPC 20180195, respectively. The Secretariat of Innovation and Business (Embrapa SIN), in Brasília (Rodovia DF 001, km 69, Caixa Postal 999, Riacho Fundo I, CEP 71805-970, Brasília/DF. Phone +55 (61) 3333-0417, e-mail: spm. ebsb@embrapa.br) is in charge of the basic plant production and licensing of seed producers.

\section{ACKNOWLEDGMENTS}

The authors thank the Brazilian Agricultural Research Corporation (Embrapa), Fundação Banco do Brasil (FBB) and the Brazilian Council for Scientific and Technological Development (CNPq), for funding, and are particularly indebted to the directors of the Escola Agrícola de Unaí-MG, the directors and associate members of Cooperabs, Comunidade da Região do Cará, in Bela Vista de Goiás-GO; the owners (Irmãos Cândido) of the Fazenda Atoleiro, Rio Pardo de Minas-MG and the owner of Tellus Alimentos, Lagoa Formosa-MG, for practical support during the experiment.

\section{REFERENCES}

Carvalho LJCB, Vieira EA, Fialho JF and Souza CRB (2011) A genomic assisted breeding program for cassava to improve nutritional quality and Industrial traits of storage root. Crop Breeding and Applied Biotechnology 11: 289-296.

Fialho JF and Vieira EA (2013) Manejo e tratos culturais da mandioca. In Fialho JF and Vieira EA (eds) Mandioca no Cerrado: orientações técnicas. Embrapa Cerrados, Brasília, p. 61-88.

Fialho JF, Sousa DMG and Vieira EA (2013) Manejo do solo no cultivo de mandioca. In Fialho JF and Vieira EA (eds) Mandioca no Cerrado: orientações técnicas. Embrapa Cerrados, Brasília, p. 39-60.

IBGE - Instituto Brasileiro de Geografia e Estatística (2016) Sistema IBGE de recuperação automática - SIDRA. Available at: <http://www. sidra.ibge.gov.br/>. Accessed on August 19, 2019.

Klink CA and Machado RB (2005) Conservation of the Brazilian Cerrado. Conservation Biology 19: 707-713.

Sano EE, Rosa R, Scaramuzza CAM, Adami M, Bolfe EL, Coutinho AC, Esquerdo JCDM, Narvaes IS, Victoria DC, Ferreira LG, Brito JLS, Bayma AP, Oliveira GH and Bayma-Silva Gustavo (2019) Land use dynamics in the Brazilian Cerrado in the period from 2002 to 2013. Pesquisa Agropecuária Brasileira 54: e00138.

Valle TL and Lorenzi JO (2014) Variedades melhoradas de mandioca como instrumento de inovação, segurança alimentar, competitividade e sustentabilidade: contribuições do Instituto Agronômico de Campinas (IAC). Cadernos de Ciência e Tecnologia 31: 15-34.

Vieira EA, Fialho JF, Carvalho LJCB, Malaquias JV and Fernandes FD (2015) Desempenho agronômico de acessos de mandioca de mesa em área de Cerrado no município de Unaí, região noroeste de Minas Gerais. Científica 43: 371-377.

Vieira EA, Fialho JF, Julio L, Carvalho LJCB, Dalla Corte JL, Rinaldi MM, Oliveira CM, Fernandes FD and Anjos JRN (2018) Sweet cassava cultivars with yellow or cream root pulp developed by participatory breeding. Crop Breeding and Applied Biotechnology 18: 450-454.

Vieira EA, Fialho JF, Julio L, Carvalho LJCB, Dalla Corte JL, Rinaldi MM, Oliveira CM, Fernandes FD and Anjos JRN (2019) BRS 400 e BRS 401, sweet cassava cultivars with pink roots developed by participatory breeding. Crop Breeding and Applied Biotechnology 19: 501-504.

Vieira EA, Fialho JF, Silva MS, Paula-Moraes SV, Oliveira CM, Anjos JRN, Rinaldi MM, Fernandes FD and Guimarães Junior R (2011) BRS Japonesa: new sweet cassava cultivar for the Distrito Federal region. Crop Breeding and Applied Biotechnology 11: 93-196.

Vilpoux OF (2008) Competitividade da mandioca no Brasil, como matéria prima para amido. Informações Econômicas 38: 27-38.

Williams HJ and Edwards TG (1980) Estimation of cyanide with alkaline picrate. Journal of the Science of Food and Agriculture 31: 15-22.

\footnotetext{
(cc) EY This is an Open Access article distributed under the terms of the Creative Commons Attribution License, which permits unrestricted use, distribution, and reproduction in any medium, provided the original work is properly cited.
} 